\title{
"DILEMA" PEMANFAATAN TEKNOLOGI KOMUNIKASI DAN INFORMASI (ICT) UNTUK MENINGKATKAN MUTU PENDIDIKAN
}

Oleh: Jaka Warsihna*

\section{Abstrak}

Perkembangan teknologi informasi dan komunikasi yang begitu cepat berdampak pada berbagai sendi kehidupan manusia. Salah satu sektor kehidupan yang mendapatkan manfaat dari perkembangan teknologi tersebut adalah pendidikan. Tidak diragukan lagi dan sudah banyak penelitian yang menunjukkan bahwa teknologi informasi dan komunikasi dapat didayagunakan untuk meningkatkan mutu pendidikan. Berbagai negara sudah memanfaatkan teknologi tersebut untuk pendidikan. Menurut UNESCO dapat dikelompokkan menjadi tiga golongan dalam pemanfaatan ICT untuk pendidikan. Satu, negara yang memanfaatkan ICT sudah terintegrasi dalam pembelajaran di kelas, dua negara yang sudah mempunyai perencanaan dan memulai melaksanakan, tiga negara pemula memanfaatkan ICT untuk pendidikan, tetapi belum ada perencanaan dan secara individu sudah mulai memanfaatkan. Indonesia termasuk negara yang kelompok ketiga, yaitu baru mulai memanfaatkan, namun belum ada perencanaan secara nasional baru secara individu atau kelompok kecil yang sudah memanfaatkanya.

\section{A. LATAR BELAKANG}

Perkembangan teknologi komunikasi dan informasi yang begitu cepat, menjadikan negara satu dengan negara lain begitu dekat.

*) Drs. Jaka Warsihna, M.Si, adalah Staf Bidang Pengembangan Media Pustekkom Depdiknas. Kandidat Doktor Universitas Negeri Jakarta 
Saat ini kejadian di suatu wilayah dalam waktu yang begitu cepat dapat diketahui oleh orang di seluruh dunia. Saat ini dunia bagaikan menjadi sebuah desa, dan batas-batas wilayah menjadi tidak begitu nyata (borderless). Bahkan sebagai dampak globalisasi mengakibatkan terjadinya persaingan secara bebas dalam dunia pendidikan dan tenaga kerja yang akan menuntut pemerintah dalam bidang ketenagakerjaan perlu melakukan perlindungan terhadap tenaga kerja sebagai akibat mekanisme pasar.

Kondisi tersebut menuntut perlu adanya suatu sistem pendidikan yang mampu menyediakan sumberdaya manusia yang mampu bersaing secara global. Oleh karena itu kebijakan nasional perlu diarahkan agar mampu menyiapkan sumberdaya manusia yang mampu menghadapi tantangan zaman secara efektif dan efisien sejak usia sekolah dengan memanfaatkan kemajuan teknologi.

Tuntutan agar pemerintah bisa menyelenggarakan sistem pendidikan yang mampu meningkatkan kualitas peserta didik dalam rangka menyiapkan mereka untuk menghadapi persaingan global, datang dari berbagai pihak yang berkepentingan terhadap masa depan bangsa. Para pakar, pemerhati, dan masyarakat pendidikan melalui Konvensi Nasional Pendidikan Indonesia (Konapsi) ke IV, diselenggarakan di Jakarta tahun 2000, mengeluarkan 11 butir rekomendasi yang tertuang dalam agenda Jakarta 2000. Dalam butir terakhir dari 11 butir merekomedasikan pemanfaatan teknologi baru yaitu teknologi komunikasi dan informasi untuk meningkatkan pemerataan dan kualitas pendidikan. Secara lengkap butir ke sebelas berbunyi "Mengoptimalkan pemanfaatan teknologi komunikasi dan informasi untuk meningkatkan kinerja sistem pendidikan nasional serta menjadikan teknologi komunikasi dan informasi tersebut agar terjangkau dan dapat dimanfaatkan oleh segenap lapisan masyarakat sebagai upaya pemerataan pendidikan (Akademisia, dalam Hardjito, 2001).

Hal ini sesuai dengan apa yang disampaikan oleh pakar komunikasi Harold Innis dan Marshall McLuhan, yang menyatakan bahwa ada 
hubungan langsung antara kelestarian medium komunikasi masyarakat dan kecepatan perubahan sosial. Konsekwensi teknologi komunikasi terhadap lingkungan tersebut lebih lanjut disampaikan oleh Pavlick (1998) yang menyatakan bahwa secara umum ada dua lingkungan masyarakat yang akan menerima dampak dengan adanya teknologi yaitu 1) sistem politik yang meliputi proses demokrasi, pelayanan pemerintahan dan partisipasi politik, dan 2) lingkungan pendidikan yang meliputi sekolah, perpustakaan, dan akses untuk tekonologi informasi.

Mengacu pada pendapat Pavlick di atas, maka bidang pendidikan merupakan salah satu lingkungan masyarakat yang akan mendapatkan dampak dengan adanya pemanfaatan teknologi baru. Hal ini apabila teknologi tersebut bisa dimanfaatkan sebagai media pembelajaran dalam upaya peningkatan kualitas proses belajar mengajar. Namun untuk dapat memanfaatkan media tersebut, perlu adanya berbagai kesiapan baik infrasturktur maupun manusianya. Apabila kedua hal tersebut tidak disiapkan maka, teknologi tersebut justru akan menjadi masalah baru bagi sekolah. Dengan demikian menjadi sebuah "dilemma" bagi sekolah antara memanfaatan media atau tidak, sebuah pilihan yang penuh resiko.

\section{B. IDENTIFIKASI MASALAH}

Dengan hadirnya teknologi baru bagi dunia pendidikan bisa membawa dampak positif apabila teknologi tersebut dimanfaatkan untuk meningkatkan kualitas pembelajaran, tetapi bisa menjadi masalah baru apabila sekolah tidak siap. Hal ini berarti kehadiran teknologi baru menjadi sebuah "dilema" bagi dunia pendidikan.

Dampak positif teknologi terhadap dunia pendidikan sudah tidak diragukan lagi. Berbagai pendapat pakar dari berbagai disiplin ilmu sepakat bahwa kehadiran teknologi baru misalnya radio, televisi, komputer, dan internet akan dapat meningkatkan kualitas pendidikan. Namun perlu disadari bahwa kehadiran teknologi tersebut di sekolah juga menimbulkan masalah, antara lain:

1. Tidak setiap sekolah mempunyai sarana yang menjadi prasarat 
pemanfaatan teknologi tersebut.

2. Menjadi beban sekolah karena harus melatih guru agar dapat memanfaatkan dengan baik, hal ini berarti membutuhkan biaya.

3. Kesadaran guru terhadap penggunaan media masih sangat rendah, karena pada umumnya guru mengejar kurikulum dengan sistem pembelajaran ceramah.

4. Kehadiran mata pelajaran Teknologi Komunikasi dan Informasi menjadi beban sekolah karena guru dan sarananya belum siap.

5. Dengan adanya peralatan baru yang relatif mahal menimbulkan masalah rawan pencurian.

6. Menambah beban orangtua karena harus bekerjasama dengan swasta yang bisa menyediakan tenaga dan perlatannya.

\section{PEMBAHASAN}

Undang-undang Dasar 1945, alinea ke empat bagian pembukaan menyatakan bahwa: “.... Pemerintah negara Indonesia melindungi segenap bangsa Indonesia dan seluruh tumpah darah Indonesia, memajukan kesejahteraan umum, mencerdaskan kehidupan bangsa, dan .... Dari pernyataan tersebut berarti bahwa pemerintah mempunyai komitmen dalam usaha mencerdaskan kehidupan bangsa melalui pendidikan. Melalui pendidikan dapat dikembangkan kualitas sumberdaya manusia Indonesia. Melalui pendidikan dapat dibangun suatu masyarakat negara Idonesia yang berdaulat dan diterima keberadaannya di lingkungan dunia Internasional.

Peranan pendidikan semakin strategis dalam menghadapi pasar global. Hanya bangsa yang berkualitaslah yang akan mampu bersaing. Kualitas suatu bangsa sangat ditentukan oleh kualitas pendidikan bangsa tersebut. Kenyataan menunjukkan bahwa untuk meningkatkan kualitas pendidikan harus dipenuhi berbagai persyaratan. Salah satunya yaitu sarana dan prasarana pendidikan yang memenuhi standar. Di dalam Peraturan Pemerintah Republik Indonesia Nomor 19 tahun 2005 tentang Standar Nasional Pendidikan pasal 42 disebutkan bahwa setiap satuan pendidikan wajib memiliki sarana yang meliputi perabot, peralatan pendidikan, 
media pendidikan, buku dan sumber belajar lainnya, bahan habis pakai, serta perlengkapan lain yang diperlukan untuk menunjang proses pembelajaran yang teratur dan berkelanjutan. Kemudian pada pasal 1, Ketentuan Umum, yang dimaksud dengan standar sarana dan prasarana adalah standar nsional pendidikan yang berkaitan dengan kriteria minimal tentang ruang belajar, tempat berolahraga, tempat beribadah, perpustakaan, laboratorium, bengkel kerja, tempat bermain, tempat berkreasi dan berekreasi, serta sumber belajar lain yang diperlukan untuk menunjang proses pembelajaran, termasuk penggunaan teknologi informasi dan komunikasi.

Hal ini menunjukkan bahwa adanya kesadaran pemerintah untuk memanfaatkan teknologi informasi dan komunikasi untuk meningkatkan pemerataan dan mutu pendidikan. Pemanfaatan teknologi komunikasi dan informasi tersebut dapat digunakan sebagai media dan sekaligus sumber belajar.

Ada lima prespektif yang bisa dilihat dalam peranan teknologi komunikasi dalam peranannya sebagai media pembelajaran (Clark, 1996), yaitu: 1) media sebagai teknologi, 2) media sebagai tutor atau guru, 3) media sebagai agen sosialisasi, 4) media sebagai motivator untuk belajar, dan 5) media sebagai alat mental untuk berpikir dan memecahkan masalah (dalam Ebersole, 2000).

Sementara itu, Winn (1996) menambahkan, bahwa ada tiga peranan media dalam pendidikan yaitu , 1) media pembelajaran, yang dalam hal ini berfungsi sebagai penyampai pesan khusus, 2) sebagai pembentuk lingkungan perantara, di mana media membantu siswa melakukan eksplorasi dan membentuk pemahaman suatu pengetahuan, dan 3) pengembangan kemampuan kognitif, di mana media dipergunakan sebagai model atau perluasan mental kemampuan.

Berbagai penelitian tentang dampak media pendidikan telah dilakukan oleh para peneliti, termasuk juga para peneliti yang secara 
khusus meneliti dampak negatif media. Dari berbagai penelitian ternyata lebih banyak dampak positif dalam penggunaan media pendidikan di kelas (Kozma, 1996).

Sesunguhnya pemanfaatan teknologi untuk keperluan pendidikan dalam hal fungsinya sebagai media pembeljaran bukanlah hal baru. Sejarah teknologi pendidikan, khususnya pemanfaatan media massa dalam konteks pendidikan, merupakan bagian dari suatu revolusi (Cuban, 1986). Penggunaan buku, film, radio, TV, multimedia interaktif, dan internet telah menjadi harapan masyarakat sebagai sarana untuk bisa membantu memecahkan berbagai masalah proses belajar mengajar dalam sistem pendidikan, merupakan upaya pemanfaatan teknologi untuk menunjang peningkatan kualitas proses belajar mengajar yang dilakukan secara konvensional.

Hal ini juga disadari oleh para pengelola pendidikan di Indonesia, terbukti penggunaan media pendidikan (Information Communication Technology) menjadi bagian di dalam penyusunan perencanaan strategis Departemen Pendidikan Nasional tahun 2005 - 2009. Dalam Renstra tersebut disebutkan bahwa dalam rangka peningkatan mutu dan relevansi pendidikan disebut perlu memperhatikan dinamika perubahan sebagai salah satu sektor pembangunan nasional juga harus dicermati dalam perspektif perubahan global, di mana teknologi informasi dan komunikasi (ICT) memainkan perannya yang sangat menentukan.

Industri ICT yang mengintegrasikan kekuatan teknologi telekomunikasi, komputer, dan informasi, telah memasuki sektorsektor strategis pembangunan, yang secara fundamental dan sistematis membawa perubahan signifikan pada aspek-aspek kecepatan, inovasi, nilai-nilai, dan kultur. Maka apabila strategi pembangunan pendidikan tidak memperhitungkan ICT, pengembangan pendidikan dapat kehilangan kontekstualitas dan relevansinya, baik pada aspek profesionalitas pengelolaan pendidikan maupun mutu pembelajaran (Depdiknas, 2005).

Pembaruan pendidikan menggunakan ICT juga dilakukan oleh 
berbagai negara, bahkan jauh lebih maju. Sebagai contoh Singapura pada tahun 1997 telah menganggarkan penyediaan dua komputer untuk setiap siswa dalam waktu lima tahun dan menerapkan teknologi informasi interaktif pada sistem persekolahannya. Sistem jaringan yang dibangun akan menghubungkan pendidikan, industri internasional berteknologi tinggi dan dunia kerja (Dryden dan Vos, dalam Renstra Depdiknas).

Contoh lainnya adalah Cina, yang sedang mengembangkan sistem jaringan khusus untuk menghubungkan 310 juta pemilik televisi sebagai perangkat untuk koneksi ke internet, yang juga dimanfaatkan untuk kepentingan pendidikan.

Sekolah-sekolah di berbagai negara seperti Beijing, Jepang, selandia Baru, Australia, dan Amerika telah berhasil merubah kultur pembelajaran dengan membawa teknologi digital dalam aktivitas bekerja dan belajar di sekolah.

Revolusi digital memicu munculnya pemikiran ulang tentang metode belajar dan mengajar. Peter Druker (1999), pakar manajemen terkemuka, menyatakan bahwa "bangsa yang benar-benar dapat memanfaatkan ledakan komunikasi digital, dan menghubungkannya dengan teknik-teknik pembelajaran baru, niscaya akan memimpin dunia di bidang pendidikan." (dalam Renstra Depdiknas, 2004).

Walaupun masih dalam lingkup yang terbatas, pembangunan pendidikan di Indonesia sudah memanfaatkan ICT dalam pengelolaan dan pembelajaran. Pendidikan kejuruan yang dikelola Dikmenjur, Depdiknas, telah merintis sistem pengelolaan dan materi pembelajaran untuk siswa SMK yang disesuaikan dengan kebutuhan keterampilan bagi dunia kerja. Program komputerisasi Dikmenjur sudah dimulai sejak tahun 1980, dan menargetkan semua SMK di Indonesia sudah terhubung ke internet pada tahun 2006. program yang sudah direalisasikan hingga tahun 2004 ialah: a) Jaringan Internet yang menghubungkan 784 SMK; b) Jaringan Informasi Sekolah di 137 Kabupaten/Kota; c) 31 Wan (Wide Area Network) di 
31 Kabupaten/Kota; d) 44 ICT Center di 44 Kabupaten/Kota; e) 8 MTU (Mobile Training Unit di 8 lokasi; dan f) School Mapping yang telah dikembangkan oleh 271 SMK (Renstra Depdiknas).

Terlepas sudah seberapa jauh pemanfaatannya, langkah pendidikan kejuruan merupakan rintisan yang baik bagi dunia pendidikan di Indonesia. Secara umum, atau dalam tataran makro strateginya, pengembangan pendidikan di Indonesia belum secara sitematis dan komprehensif memanfatkan ICT untuk kepentingan pendidikan. Kurikulum Teknologi Komunikasi dan Informasi sebagai salah satu subjek pembelajaran, baru ditetapkan tahun 2004/2005, dan masih terbatas untuk SMK dan SMA. Konten pembelajaran, belum disusun dengan landasan konsep yang mendalam dari segi makna dan manfaat dalam konteks kepentingan pendidikan. Materi kurikulum, khususnya di sekolah menengah umum, lebih diorientasikan pada penguasaan keterampilan praktis menggunakan program aplikasi seperti program mengolah kata (MS Word).

Dalam konteks makro nasional, pemanfaatan ICT di Indonesia memang masih amat tertinggal bila dibandingkan dengan negaranegara lain. Indikasi mengenai hal ini dapat dilihat denga data berikut (tahun 2003). Kepemilikan komputer (PC) per 100 orang di Indonesia masih sangat rendah, yaitu baru mencapai 1,19 ; sementara Hongkong sudah mencapai 42,20; Jepang 38,22; Korea 55,80; Kuwait 16,10; Malaysia 16,69; Singapura 62,20; Taiwan 47,14; Thailand 3,98; dan China '!,76. dari jumlah pemakai internet, Indonesia 2,5 juta, India 7,5 juta, Korea 26,7 juta, Malaysia 4,2 juta, dan Taiwan 10,6 juta. Dari jumlah pemasang situs internet, Indonesia 62 juta, Korea 3822 juta, Malaysia 107 juta, singapura 484 juta, Taiwan 2777 juta, dan Thailand 103 juta (UNESCO dalam http://www.Depdiknas.go.id)

Menurut UNESCO hasil pertemuan negara-negara Asia-Pasific 2004, ada tiga kategori negara-negara pengguna ICT untuk pendidikan, yaitu: 
- Advanced countries (integrating ICT into the education system)

- Countries with national ICT policies and master plans, applying and testing various strategies but not fully integrating ICT within education

- Beginning countries, either with national policies, but not enough resources to implement their policies and work plans, or without policies, but running pilot ICT projects

Dari ketiga kategori tersebut Indonesia adalah kategori yang ketiga, yaitu negara yang baru mulai memanfaatkan ICT untuk pendidikan belum ada kebijakan secara nyata, sumber daya manusianya belum mencukupi untuk mengimplementasikan ICT dalam pendidikan.

Saat ini baru mulai ada kesadaran dari pemerintah pusat untuk memanfaatkan ICT dalam peningkatan mutu pendidikan. Hal ini termuat di dalam Renstra Depdiknas tahun 2005-2009 halaman 36 , secara nyata disebutkan bahwa peningkatan mutu pendidikan akan lebih signifikan, relevan, dan kontekstual apabila manajemen pendidikan dan proses pembelajaran memanfaatkan kemajuan ICT. Untuk manajemen pendidikan, penerapan ICT dapat dilakukan dengan membangun aplikasi manajemen, penyediaan data yang lengkap, akurat, up-to-date, mudah diakses dan murah, yang akan berdampak pada peningkatan profesionalitas pengelolaan pendidikan. Sistem jaringan on-line dan database terpusat, bermanfaat untuk mempercepat, mempermudah, dan mengefisienkan pelaporan, korespondensi, komunikasi, dan sosialisasi/publikasi informasi-informasi pendidikan.

Peningkatan mutu pembelajaran dengan penerapan ICT dilakukan dengan mengembangkan aplikasi pembelajaran dalam model pemebelajaran interaktif yang menyenangkan dan mengasyikan. Aplikasi pembelajaran yang dapat dikemas dalam format multimedia interaktif akan dikembangkan dalam fungsinya sebagai tutorial (Computer-based Instruction) dan learning tool (alat pembelajaran). Dengan sistem jaringan on-line (internet, intranet, LAN), pembelajaran dapat dirancang dalam model pembelajaran 
alternatif dengan pendekatan multi-disiplin dan berkolaborasi, sehingga proses pembelajaran menjadi lebih menyenangkan dan mengasyikan, yang selanjutnya membuat pembelajaran menjadi lebih efektif.

Namun dalam aplikasinya melihat kondisi Indonesia yang begitu beragam baik sarana di sekolah, latar belakang ekonomi, pendidikan orangtua, kemampuan guru, bahkan secara geografis sangat sulit untuk menerapkan ICT untuk pendidikan. Dengan berbagai kendala dan kondisi yang ada akhirnya penerapan ICT di sekolah menjadi sebuah dilema. Satu pihak kalau tidak menerapkan ICT akan sulit untuk meningkatkan mutu pendidikan, sebab dalam kenyataan pendidikan secara konvensional sampai saat ini hasilnya belum begitu menggembirakan. Namun di pihak lain dengan penerapan ICT menjadi masalah baru bagi sekolah. Masalah yang timbul dengan penerapan ICT di sekolah dapat diidentifikasi sebagai berikut:

\section{Sarana di sekolah belum memadai}

Pustekkom sudah sejak tahun 1976 membuat berbagai program media pembelajaran untuk membantu meningkatkan mutu pendidikan. Media yang dibuat pada saat itu yaitu melalui kaset audio. Kaset audio itu kemudian disiarkan melalui kerjasama dengan Radio Republik Indonesia di pusat kemudian direlay oleh RRI daerah. Ketika sistem ini diujicobakan di wilayah Yogayakarta dan Jawa Tengah sambutannya sangat luar biasa dan memang secara nyata dapat meningkatkan mutu pembelajaran, karena siswa lebih bersemangat belajarnya dan pelajaran menjadi lebih variatif. Namun ketika sistem ini diterapkan di wilayah lain, misalnya di Kalimantan Timur, Sulawesi Tengah, Nusa Tenggara Barat, ternyata menimbulkan masalah baru. Pertama sekolah tersebut belum mempunyai pesawat radio, kedua aliran listriknya belum ada, ketiga siaran radio itu tidak bisa ditangkap dengan baik oleh sekolah. Berdasarkan data dari Pusat Informasi Pendidikan, Balitbang, Depdiknas tahun 2004 seluruh sekolah di Indonesia dari tingkat SD sampai SLTA baru sekitar $15 \%$ yang mempunyai aliran listrik. 
Karena kondisi tersebut, akhirnya sekolah tersebut menjadi merasa terbebani, sehingga pihak sekolah menjadi enggan untuk menjadwalkan siaran pendidikan tersebut untuk dimanfaatkan di sekolah.

Begitu juga kasus pemanfaatan siaran Televisi Pendidikan Sekolah yang disiarkan oleh Televisi Pendidikan Indonesia (TPI) tahun 1990 sampai dengan 1995, dan sekarang siaran Televisi Edukasi, pada umumnya karena masalah sarana, misalnya belum adanya ruang khusus untuk pemanfaatan media pembelajaran.

\section{Keterbatas biaya dan tenaga operasional}

Untuk bisa memanfaatkan berbagai media pembelajaran baik media transparansi, audio, video, atau komputer perlu adanya tenaga khusus yang mengelola media tersebut, karena tidak setiap guru akrab dengan berbagai media tersebut. Berbagai sekolah yang mempunyai kemampuan baik tenaga maupun biaya tidak menjadi masalah, tetapi bagi sekolah yang miskin dan tenaga gurunya pas-pasan kondisi ini merupakan masalah baru yang sangat sulit untuk mengatasinya. Berdasarkan hasil pemantauan yang dilakukan oleh Pustekkom pada tahun 2004 terdahap pemanfaatan video pembelajaran salah satu kendala utamanya adalah di sekolah tersebut belum ada tenaga operasional khusus yang mengelola media tersebut, sehingga penjadwalan dan perawatan dan mengoperasionalkan ketika guru akan memanfaatkan menjadi masalah. Akhirnya guru malas untuk memanfaatkan media tersebut.

Begitu juga dalam pemanfaatan program multimedia interaktif dan internet. Banyak sekolah yang belum mempunyai tenaga yang bisa mengoperasionalkan komputer dan internet dengan baik. Kondisi ini menjadi masalah yang sangat sulit dipecahkan oleh sekolah, terutama sekolah yang kurang mampu dan 
pimpinannya kurang mendukung.

\section{Kesadaran Kepala Sekolah dan Guru}

Secara umum kondisi sekolah di Indonesia memang kesulitan untuk mencari tambahan biaya untuk kegiatan yang di luar kegiatan rutin. Pemanfaatan media pendidikan bagi sekolah kesannya sangat mahal dan menakutkan sehingga kalau sekolah tersebut pimpinannya dan guru-gurunya kurang sadar pentingnya media pendidikan, akan semakin jauh dari harapan untuk memanfaatkan media pendidikan.

Berdasarkan hasil penelitian yang dilakukan oleh Pustekkom tahun 2004, SMP dan SMA yang sudah memiliki media video pembelajaran sudah baik dengan cara membeli atau mendapatkan bantuan sekitar $10 \%$. Dari jumlah tersebut hanya $1,5 \%$ yang secara rutin memanfaatkan media tersebut untuk pembelajaran. Salah satu alat ukurnya yaitu adanya jadwal pemanfaatan di sekolah.

Ketika dilakukan wawancara terhadap guru, alasan yang secara umum adalah 1) belum tahu kalau mempunyai media tersebut; 2) belum tahu cara memanfaatkannya; 3) materi yang diperlukan tidak ada; 4) belum ada jadwal pemanfaatannya; 5) untuk memanfaatkan harus pakai prosedur; 6) medianya tidak terawat dan sudah rusak; dan 7 ) belum ada petunjuk dari Kepala Sekolah.

Namun ketika dilakukan wawancara terhadap Kepala Sekolah yang cukup mengagetkan meskipun alas an yang di sampaikan bersifat klasik, yaitu 1) takut rusak; 2) media dibawa pulang karena di samping sekolah tidak aman; dan 3) takut target kurikulum tidak terpenuhi.

\section{Beban orangtua siswa lebih berat}

Beberapa sekolah yang telah mempunyai kesadaran tentang pentingnya media untuk pembelajaran, mulai memanfaatkan 
berbagai media, misalnya video pembelajaran, program multimedia, dan internet. Terlebih lagi dengan berlakunya kurikulum 2004 yang menuntut berbagai sumber belajar untuk memperkaya pengetahuan guru dan siswa. Untuk memenuhi hal tersebut sekolah mau tidak mau harus mencari berbagai sumber dana. Salah satu sumber dana yang paling banyak dilakukan sekolah dan mudah adalah dibebankan kepada orangtua siswa. Kalau hal ini diterapkan oleh seluruh sekolah, tentu saja akan menjadi beban yang tidak ringan bagi orangtua siswa.

Apalagi sering kita dengar ada anak yang rela mau bunuh diri karena malu belum membayar uang sekolah. Kemudian banyak yang untuk makan saja sangat sulit, apalagi untuk biaya sekolah, bahkan banyak anak yang mengalami gizi buruk (busung lapar). Melihat kondisi seperti ini tentu saja beban pemerintah menjadi semakin berat, boro-boro bicara teknologi kalau makan saja susah.

\section{Kondisi keamanan sekolah}

Sudah sejak lama Pustekkom dan beberapa Direktorat memberikan bantuan berupa berbagai media pembelajaran, ke sekolah. Ketika barang-barang tersebut dicek di sekolah ada yang dimanfaatkan dengan baik dan ada juga yang tidak dimanfaatkan. Bagi sekolah yang tidak memanfaatkan media tersebut, ketika dilakukan pengecekkan terhadap Kepala Sekolah, Guru, dan Pengawas, ada beberapa alasan, antara lain masalah keamanan. Misalnya barangnya hilang karena dicuri orang, barangnya disimpan di rumah Kepala Sekolah karena takut hilang (Radio dan TV), barangnya disimpan karena takut rusal, dan lain sebagainya.

Melihat kondisi ini, artinya pihak sekolah merasa terbebani dengan adanya bantuan barang tersebut karena harus menjaga keamanan. Kalau keamanannya saja tidak terjamin bagaimana mau bisa digunakan untuk peningkatan mutu pendidikan/ 
pembelajaran.

\section{Persepsi yang salah terhadap media pembelajaran}

Alasan yang sering kita dengar, mengapa guru enggan memanfaatkan media pembelajaran karena dengan memanfaatkan media tersebut jam pelajaran siswa menjadi terganggu. Selama ini, guru mengajar di kelas sesuai dengan tuntutan kurikulum. Artinya karena beban kurikulum yang harus diajarkan oleh guru begitu banyak, maka kalau di dalam pelajaran memakai media justru akan mengurangi waktu yang seharusnya digunakan untuk menyampaikan materi yang ada di buku paket.

Kondisi ini memang cukup memprihatinkan. Artinya persepsi guru terhadap media pembelajaran salah. Padahal seharusnya justru dengan bantuan media, materi yang disampaikan menjadi lebih jelas dan komprehensif karena pemahaman siswa diharapkan hampir sama.

Untuk mengatasi kondisi ini, perlu adanya sosialisasi yang benar terhadap pemanfaatan media pembelajaran, sehingga kesadaran guru untuk memanfaatkan media menjadi lebih baik.

\section{Guru merasa terbebani}

Untuk bisa mengajar dengan memanfaatkan media, memang dituntut guru harus lebih kreatif serta persiapan pengajaran lebih matang. Sebelum mengajar menggunakan media, guru di rumah sudah harus mencobanya sehingga nantinya di sekolah, guru sudah terbiasa dan tidak canggung lagi. Untuk itu, guru perlu menyiapkan waktu, tenaga dan biaya agar bisa berjalan lebih baik.

Namun dalam kenyataan dengan alasan tidak ada waktu, tidak ada biaya, dan lain-lain, guru beralasan untuk tidak menggunakan media. Kondisi ini memang perlu proses untuk memberikan kesadaran, sebab sudah menjadi suatu sifat manusiawi bahwa seseorang itu ketika ada suatu yang baru 
cenderung untuk sulit berubah atau menerima untuk memahami dan mempelajarinya.

\section{Medianya terbatas}

Saat ini lembaga pemerintah yang membuat berbagai media belum begitu banyak. Pustekkom misalnya membuat modul, media audio/radio, video/televisi, multimedia/komputer, dan edukasinet/internet sedangkan Pusgrafin membuat media cetak. Sementara itu lembaga swasta juga belum banyak, misalnya baru elekmedia (video animasi, dan multimedia interaktif).

Dalam kondisi tersebut di atas berarti ketersediaan media pembelajaran belum begitu banyak dan lengkap untuk seluruh jenjang. Dengan demikian, ketika guru ingin memanfaatkan media harus memanfaatkan media yang ada meskipun mungkin bukan yang diinginkan atau membuat sendiri. Untuk membuat sendiri, memang memerlukan waktu, tenaga, dan biaya yang besar sehingga jarang guru yang bisa membuatnya. Kalau ingin memanfaatkan internet yang relatif banyak dan lengkap informasinya, guru mungkin mempunyai kendala dengan bahasa Inggris, atau biaya karena untuk akses internet di Indonesia bagi kantong guru masih relatif mahal.

\section{KESIMPULAN}

a. Pemanfaatan media untuk meningkatkan mutu pendidikan di sekolah sudah tidak diragukan lagi karena pembelajaran lebih efektif dan efisien.

b. Berbagai penelitian dan pendapat pakar sudah banyak yang menyatakan bahwa media sangat efektif untuk meningkatkan mutu pendidikan. Bahkan dengan media pendidikan, sekolah menjadi lebih dekat dengan dunia kerja dan tuntutan zaman.

c. Namun dengan pemanfaatan media ini di beberapa sekolah bahkan sebagian besar sekolah di Indonesia mempunyai 
masalah atau menimbulkan masalah baru. Dalam kondisi ini sekolah tersebut menjadi suatu "dilemma" artinya kalau tidak memanfaatkan media (secara konvensional), maka akan sulit untuk mengikuti perkembangan zaman dan sekolah akan terus tertinggal dengan sekolah lain. Namun kalau memanfaatkan media, maka sekolah tersebut mempunyai berbagai masalah yaitu:

- Sarana di sekolah belum memadai;

- Keterbatas biaya dan tenaga operasional;

- Kesadaran Kepala Sekolah dan Guru ;

- Beban orangtua siswa lebih berat;

- Kondisi keamanan sekolah;

- Persepsi yang salah terhadap media pembelajaran;

- Guru merasa terbebani; dan

- Media yang ada masih terbatas.

\section{E. SARAN-SARAN}

a. Kebijakan dalam pemanfaatan media di sekolah harus disesuaikan dengan kondisi yang ada di sekolah tersebut.

b. Penerapan mata pelajaran Teknologi Komunikasi dan Informasi tidak bisa dipaksakan kepada seluruh sekolah apabila sekolah tersebut belum siap.

c. Pemerintah pusat dan daerah perlu sinerji untuk menyediakan media yang murah dan mudah dimanfaatkan oleh sekolah.

d. Pemerintah perlu mensosialisasikan kepada guru tentang pentingnya memanfaatkan media dalam pembelajaran, sehingga kesadaran guru lebih baik lagi.

e. Pemerintah perlu melengkapi sarana yang diperlukan untuk pemanfaatan media, misalnya listrik, radio, televisi, komputer, dan jaringan internet yang murah.

f. Perlunya diberikan kesadaran kepada suluruh stakeholder pendidikan agar memberikan dukungan demi kemajuan pendidikan. 


\section{DAFTAR PUSTAKA}

Cuban, L. 1996, TECHNO-REFORMERS AND CLASSROOM TEACHERS, education Week on the Web, (online) Available: http:/ /www.edweek. Org/ew/vol-16/06cuban

Depdiknas, 2004, PERENCANAAN STRATEGIS TAHUN 2004-2009. Depdiknas, 2005, PERATURAN PEMERINTAH NO 19 TAHUN 2005 TENTANG STANDAR BASIONAL PENDIDIKAN.

Ebersole, Samuel, 2000. USES AND GRATIFICATION OF THE WEB AMONG STUDENT, Journal of Computer mediated Communication 6, (online) Avaliable at http://www.ascuse.org/jcmc/vol16/issue1/ ebersole.html.

Hardjito, 2001, POLA HUBUNGAN FAKTOR-FAKTOR YANG MEMPENGARUHI PEMANFAATAN INTERNET: Studi Survei Motif Pemanfaatan Internet Siswa SMU dan SMK DKI Jakarta. UI. http://www.Pusinfo.go.id, LAPORAN UNESCO.

Kozma, R.B. 1996, ISSUES AND NEEDS IN EVALUATING THE EDUCATIONAL IMPACT OF THE NATIONAL EDUCATION ENFRASTUCTURE, (online) Avaliable: http://www.ed.gov/ Technology/Futures/Kozma.html.

Pavlik, John V. 1998, NEW MEDIA TECHNOLOGY, CULTURAL AND COMMERCIAL PERSPECTIVES, Second Edition, Viacom Company, USA.

Pustekkom, 2003, PAPARAN HASIL SEMINAR DI BANGKOK, UNESCO.

Undang-Undang Dasar Negara RI 1945, 2002. MPR-RI

Winn, W.D. 1996, COMMUNICATION, MEDIA, AND INSTRUMENTATION, International Encyclopedia of Education Technology, Second edition, Cambridge University Press, Cambridge, UK. 